\title{
Benign Fibrohistiocytic Neoplasm
}

National Cancer Institute

\section{Source}

National Cancer Institute. Benign Fibrohistiocytic Neoplasm. NCI Thesaurus. Code C6490.

A benign mesenchymal neoplasm composed of fibrohistiocytic cells, spindle fibroblastic cells, and histiocytes, in a storiform pattern. 